\title{
LAS CANCIONES DE LOS PECES DE FEDERICO GARCIA LORCA HIJO DEL AGUA
}

\section{Constantino Láscaris}

F.G.L.

CANTA

..., me sentaré

sin pregunta y con respuesta!

Abandono

Martín Heidegger señaló que la pregunta encierra la respuesta. La forumulación de la pregunta, en la mente del filósofo, formula la explicitación de la pregunta misma como respuesta a la pregunta.

La historia de la filosofía es la sucesión de esas preguntas engendradoras de respuestas. Y claro está que las preguntas llevan al hombre a dominar el mundo.

El poeta, Federico García Lorca, no se hacía ni hacía preguntas. El mismo lo reconoció, en una carta: "Yo no soy inteligente, ;es verdad!", y ciertamente nada tuvo de filosófo. Pero añadió: "Pero soy poeta" (1). Es decir, no necesita formular preguntas para enunciar respuestas: "sin pregunta y con respuestas". No se trata de que tuviera ocurrencias ni genialidades; éstas las tienen las gentes corrientes. Era un genio, y como lo era, en él brotaban las respuestas en forma de canciones. La lengua, acervo del pensamiento colectivo de un pueblo a través del tiempo, aflora a través de los labios del poeta en forma de canciones creadoras del sentido del mundo:

Cantar que vaya al alma de las cosas

Cantos nuevos

Esa "alma de las cosas" solo es alma de las cosas en la canción, y no en las cosas mismas, que sólo llegan a ser sí mismas en la canción.

Y veo secarse los lirios

al contacto de mi voz

manchada de luz sangrienta, y en mi lírica canción

llevo galas de payaso...

Cantos nuevos

Es la voz de F.G.L. la que crea los lirios para siempre, por fuera de los lirios que se secan, y que se secan precisamente al contacto con los lirios- para--siempre de la canción. Es "la creación del ser por la palabra", por volver a establecer la eferencia al filósofo por excelencia, Martín Heidegger, la misión del poeta: el poeta crea el ser del lirio que-se seca precisamente al cantarlo para siempre como tal. Da la respuesta sin pregunta, a costa de su propio ser:

... mi vida, marchita de cantares",

Madrigal de verano

Y ello es posible por esa fuerza creadora del hombre concreto que canta:

Cada canción es mi remanso del amor. 
No voy yo a explicar lo que F.G.L. consideró "misterio indescifrable". Me limito a apuntarlo. $Y$ de paso a señalar que el poeta canta o no es poeta, sino prosista. F.GL. fue cantor -cantor de bellas canciones.

"La creación poética es un misterio indescifrable, como el misterio del nacimiento del hombre. Se oyen voces no se sabe dónde, y es inútil preocuparse de dónde vienen. Como no me he preocupado de nacer, no me preocupo de morir. Escucho a la Naturaleza y al hombre con asombro, y copío lo que me enseñan sin pedantería y sin dar a las cosas un sentido que no sé si lo tienen. Ni el poeta ni nadie tienen la clave y el secreto del mundo. Quiero ser bueno. Sé que la poesía eleva y, siendo bueno, con el asno y con el filósofo creo firmemente que si hay un más allá, tendré la agradable sorpresa de encontrarme en él. Pero el dolor del hombre y la injusticia constante que mana del mundo, y mi propio cuerpo y mi propio pensamiento, me evitan trasladar mi casa a las estrellas. Entrevista.

Y entonces, bajó las estrellas a su casa: la canción.

\section{LA CANCION AÑEJA DEL PAIS DE NINGUNA PARTE}

Una canción, para cantar, tiene que ser añeja .

Añeja no tiene nada que ver con vieja. Añeja es madurada por el tiempo, enriquecida por el fermento de las voces humanas. El vino añejado se mide por los años, pero se cata en el paladar, exactamente como la canción.

Bebe el agua tranquila de la canción añeja.

Balada de la Placeta

$\mathrm{Y}$ no es simplemente por hacer una perífrasis, pero el agua de la canción añeja se vierte en la canción del gua.

Porque desde Homero no ha habido un cantor del agua como F.G.L.

No que le haya hecho un canto. Los cantos al agua, y las trepidaciones románticas ante el mar, son temas poéticos de la mayor difusión (en cantidad y en calidad). F.G.L. canta canciones del agua al agua, y el agua trasparece en todos sus mundos poéticos. F.G.L. repudió lo desierto, lo seco, y necesitó lo fecundo de los ríos y el mar.

Veamos primero sus canciones al agua.

De 1919, La balada del agua del mar.

\section{El mar}

sonríe a lo lcjos.

Dientes de espuma,

Fábios de cielo,

¿Qué vendes, oh joven turbia con los senos al aire?

- Vendo, señor, el agua

de los mares.

- Esas lágrimas salobres

¿de dónde vienen, madre?

- Lloro, señor, el agua

de los mares.

- Corazón, y esta amargura seria, ¿de dónde nace?

- ¡Amarga mucho el agua de los mares!

El mar

sonríe a lo lejos.

Dientes de espuma,

labios de cielo.

F.G.L. no era hombre de costas, sino de tierra adentro. Pero de tierra de ríos, y cuando quería despertar el alma, era el mar de Málaga quien lo revivificaba:

Hombres de acantilado y mar abierto, $y$, por lo tanto, libres como nadie.

Mariana Pineda

Y por ella cantó F.G.L. el Canto Nocturno de los Marineros Andaluces:

De Cádiz a Gibraltar

¡que buen caminito!

El mar conoce mi paso

por los suspiros. 
¡Ay muchacha, muchacha, cuánto barco en el puerto de Málaga!

Y sigue cantando (Carmona, Sevilla, el caballo, la media luna, un corazón), hasta ese final tan humano:

Cuánto barco en el puerto, y en la playa ¡qué frío!

Porque esta canción, pese a su título, no es de los marineros andaluces, sino de F.G.L. al mar andaluz.

La tercera gran canción añeja es Mañana, de 1918.

Y la canción del agua

es una cosa eterna.

Entresaco:

Es la savia entrañable que madura los campos.

Es sangre de poetas

...

¡qué armonías derrama

al brotar de la peña!

$\cdots$

Escuchad los romances

del agua en las choperas.

Ella es luz hecha canto

...

Ella es niebla y es rosa

Miel de luna que fluye

...

Es el amor que corre

todo manso y divino,

es la vida del mundo,

la historia de su alma.

Agridulce en que tantos

sus espíritus lavan,

$$
\text { ... }
$$

F.G.L. cantó estas tres canciones añejas al agua, y a lo largo de sus canciones, rebrota el agua cantada intermitentemente. Como veremos, agua que poéticamente invade el mundo (la identidad mágica campos-mar) y que llega a albergar los astros.

La ciencia de los cantos por los cantos la tienen

los bosques rumorosos y las aguas del mar.

\section{Los álamos de plata}

Los cantos por los cantos canta la canción. Los cantos que no necesitan a la petenera o al barco, ni a la guitarra, ni al marica. Los cantos que bullen de vida y armonía por sí mismos, los cantos añejados en el agua de, las aguas:

se ha muerto un hada; el hada del campo y del mar.

\section{El maleficio de la mariposa.}

Al cantar la muerte del hada, el poeta la ha engendrado eternamente viva en su ser cantado. La misma canción canta nuevamente la viva muerte del hada:

Fuí junto a los troncos del viejo encinar y vi muerta el hada del campo y del mar.

El hada del campo y del mar respira en la canción que tanto es cantar al agua como cantar el agua:
... Mansas
y turbias de penumbra yo sentía
las canciones del agua.

Manantial

El agua que canta y el poeta que canta al agua realizan la comunión cósmica:

El mar es
El Lucifer del azul.
El cielo caído
por querer ser la luz.

$\mathrm{Y}$ de noche, todo es agua... si la luna, agua ardiente celeste, plata líquida sideral, la multiplica: 
Cuando sale la luna,

el mar cubre la tierra

y el corazón se siente

isla en el infinito.

\section{La luna asoma}

Bernarda, la Bernarda de La Casa de Bernarda Alba, la mujer del corazón seco y los ojos secos, la mujer sin canción, se estruja al gritar: "Es así como se tiene que hablar de este maldito pueblo sin río, pueblo de pozos...".

Por el contrario, ;el mar! :

“... es probable que (vaya) a Málaga (la ciudad que más quiero de toda Andalucía, por su maravillosa y emocionante sensualidad en carne viva), donde veré el mar, la única fuerza que me atormenta y me turba de la Naturaleza... ¡Más que el cielo! ¡Mucho más!

"Ahora mismo me pondría a decirte muchas cosas del mar..., pero que las oyera el mar!. Frente al mar olvido mi sexo, mi condición, mi alma, mi don de lágrimas..., ;todo! Solo me pincha el corazón un agudo deseo de imitarlo y de quedarme como él, amargo, fosfórico y desvelado eternamente".

"Es curioso que yo no tenga envidia ni deseo cosas de hombre, sino cosas a las Cosas..."

Carta, 1923.

F.G.L. no quería sequedades. Granadino de la vega que se asomaba al mar, amaba sus ríos y junto a ellos se sentía lleno de canciones:

"Creo que mi sitio está entre estos chapos musicales y estos ríos líricos, que son un remanso continuado, porque mi corazón descansa...", confesaba en una carta (2).

$\mathrm{Y}$ da la definición esencial del carmen granadino, marco adecuado para el cantor de las canciones del agua: "vivir en un carmen, y lo demás es tontería; vivir cerca de lo que uno ama y siente. Cal, mirto y surtidor" (3).

Esos ríos -remansos-- continuados, esos surtidores tienen haditas, que F.G.L. no quiso mostrarle a Juan Ramón Jiménez:

"Un día (Juan Ramón Jiménez) me dijo: "Iremos a las cinco de la cinco de la tarde, que es la hora en que empieza el sufrimiento de los jardines". Esto lo retrata de cuerpo entero, ¿verdad? y viendo la escalera del agua dijo:

"En otoño, si estoy aquí, me muero". Y lo decía convencidísimo. Hemos charlado largo rato sobre las hadas y me he guardado muy bien de enseñarle las haditas del agua, pues esto no lo hubiere podido resistir. Ya te contaré más cosas y los descubrimientos emocionantes que he hecho en el mundo fantástico de Granada" (4).

Cuando quiera describir su llegada a $\mathrm{La}$ Habana, en 1933, volviendo desde Nueva York, en una entrevista dijo:

"Pero ¿qué es esto? ¿Otra vez España? ¿Otra vez la Andalucía mundial? Es el amarillo de Cádiz con un grado más, el rosa de Sevilla tirando a carmín y el verde de Granada con una leve fosforescencia de pez: La Habana surge entre cañaverales".

Y canta, en prosa, ¡tan bellamente cantada! , al Darro y al Genil como las únicas sendas al país de Ninguna Parte. Ese país de Ninguna Parte que toda su vida buscó con los ojos y los oídos, y que hoy encontramos en sus canciones:

Amo el agua clara y la estrella turbia (5)

El agua clara, la estrella turbia, las canciones de Ninguna Parte. Tememos las únicas sendas:

"El otoño convierte a la Vega (de Granada) en una bahía sumergida. En el cubo de la Alhambra ¿no has sentido ganas de embarcarte? ¿no has visto las barcas ideales que cabecean dormidas al pie de las Torres? Hoy me doy cuenta, en medio de este crepúsculo gris y nácar, de que vivo en una Atlántida maravillosa. 
"Estoy deseando de marcharme y, sin embargo, no quisiera partir hasta que todo no estuviera dorado".

"Los valles del Darro y del Genil en esta época otoñal son las sendas de este mundo que os llevarían al país de Ninguna Parte, que debe estar entre aquellas nieblas de rumor".

"Yo no estoy ni triste ni alegre; estoy dentro del otoño; estoy ..." (6).

\section{LAS BATALLAS DE LOS PECES}

Los dos peces siderales se reflejan en la luna y la luz de la luna es un pez que se zambulle en el agua. Al amanecer, ese pez se cobija en el abismo y es sustituido por otro:

Verde que te quiero verde.

Grandes estrellas de escarcha, vienen con el pez de sombra

que abre el camino del alba.

Romance

El pez de sombra anuncia el amanecer con su lenta disolución en la luz, y entonces:

En el río ahora comienzan

las batallas de los peces.

\section{¡Amanecer y repique!}

$¡ Y$ en el mar...!

El silencio sin estrellas, huyendo del sonsonete, cae donde el mar bate y canta su noche llena de peces.

Preciosa

Esa noche es la noche del abismo marino, noche llena de peces que pelean las batallas de los peces:

Hombre y pez en sus medios, bajo

cosas flotantes,

esperando en el alga o en la villa

su noche
$\mathrm{Y}$ todo lo existente se sintetiza en pez y hombre, porque el hombre se siente solo en medio de la batalla cósmica de los peces:

Yo.

¡Solo yo!

Labrando la bandeja

donde no irá mi cabeza.

¡Solo yo!

Canción inútil

F.G.L. prepara su holocausto, pero, a diferencia del Yokanaán de Oscar Wilde, no espera sentir en los labios de su cabeza cortada el beso de una Salomé.

$Y$ cuando un hombre se siente en el desasociego, se le seca la boca y pide agua, como aquel gitano:

\section{CANCION DEL GITANO APALEADO}

Veinticuatro bofetadas

Veinticinco bofetadas;

después, mi madre, a la noche,

me pondrá en papel de plata,

Guardia civil caminera, dadme unos sorbitos de agua.

Agua con peces y barcos, Agua, agua, agua, agua.

...

Agua para beber..., agua para vivir. Pero un gitano necesita que sea plenamente agua esa "agua con peces y barcos"; peces en la noche del abismo, barcos a la vista. "Los peces de plata salen a tomar la luna y tú (Ana María Dali) te mojarás las trenzas en el agua..." (7). La sirena y los peces a la luz de la luna..., a la luz de los peces siderales, lunáticos, y por identidad, una caracola los traslada al corazón de F.G.L.:

Mi corazón

se llena de agua

con pececillos

de sombra y plata.

Los peces, en la órbita sideral, en la luna, en el río, en la sombra, en el corazón, batallan "con 
una lógica de pez en el agua..." (Poemas en prosa, Santa Lucía...), libre deambular elástico más veloz que la vista humana: “ ¿no te angustia la idea de un mar con todos los peces atados con cadenita a un solo punto, sin conciencia?" (8).

En el mundo de la generación y corrupción, como decían los griegos, de la luna para abajo, los hombres ven peces donde hay peces, $\mathrm{y}$ ven peces en la luna, en los campos y en el mar.

Un viejo Dios silvestre da frutas a los niños

Sus pescadores adermen, sin ensueño, en la arena.

En alta mar les sirve de brújula una rosa. El horizonte virgen de pañuelos heridos junta los grandes vidrios del pez y de la luna.

\section{Oda a Salvador Dali}

\section{CANCION DE PISCIS}

F.G.L. no manifestó interés por la astrología ni por las doctrinas pitagóricas. Sin embargo, en sus canciones hay un eco, muy concreto, de los peces siderales, la casilla piscis del Zodíaco.

La noche sin estrellas (ni planetas) está muerta y es para los muertos. En el Canto por Ignacio Sánchez Mejia lo vemos en cuerpo presente:

\section{que se pierda en la noche sin canto de l.. los peces}

En esas noches negras, no se oye la canción de piscis (9). Lázaro resucitado: "Tuvo predilección por el silencio de otra órbita que arrastran los peces y se agachaba lleno de terror siempre que pasaba por un arco" (Poemas en prosa, Santa Lucia y San Lázaro).

Ese "silencio de otra órbita que arrastran los peces" sería, en astronomía pitagórica, una nota musical; silencio, pues, en cuanto nota, integrado, armonía. Es "el almohadón del cielo" (Venus), que Venus señala: identidad de la concha de Venus y de la esfera celeste de Piscis.

Esa música es oída y cantada por el poeta en Nueva York: el increíble cocodrilo quieto bajo la tierra protesta de los astros.

\section{Ciudad $\sin s u e \tilde{n} o$}

Y si recordamos que: "El mar es... El cielo caído..." (Mar); tenemos la identidad mágica de los dos abismos. Pero los dos piscis, en F.G.L., a veces se separan: "Por la luna nadaba un pez" (Vals en las ramast. Y la luz de la luna, muchas veces, será a su vez un pez...

No sé, no he logrado saber, el origen histórico de la denominación en Mesopotamia de la casilla del Zodíaco como piscis. F.G.L. tampoco lo sabía.

Pero sabía que los peces navegan una órbita sideral, y que la plateada luz de la luna es reflejo escamoso de grandes peces.

\section{LAS PALABRAS DE LOS PECES MUDOS}

Ya desde la antigüedad, los poetas se habían percatado de la mudez de los peces. Empédocles recordaba haber sido, en sucesivas transmigraciones, "muchacho y muchacha, un arbusto y un ave y pez mudo en el mar". La excepción son los delfines: por ello no podrán ser peces...

Pez mudo por el agua de ancho ruido, lascivo se bañaba en el temblante, luminoso marfil, recién cortado al cuerno adolescente de la luna.

Noche de Soledad Insegura

Pero a pocos versos, en la misma canción, oímos:

Palabras de cristal y brisa oscura redondas, sí, los peces mudos hablan.

O dicho sin cantar: los peces mudos sí hablan palabras redondas de cristal y brisa oscura...

En algún momento, cada pez será él mismo una de las palabras habladas:

La mar no tiene naranjas

ni Sevilla tiene amor.

Morena, iqué luz de fuego!

Préstame tu quitasol. 
Me pondrá la cara verde, zumo de lima y limón.

Tus palabras - pececillosnadarán alrededor.

¡que el mar no tiene naranjas

ni Sevilla tiene amor!

Adelina en el paseo

O bien, cada palabra de Adelina (de aquella morena, y del poema mismo a Adelina) es un pececillo, pues son palabras dulcemente sonoras.

Y ya, cuando-escribe a Falla una carta, 1922, "hablan los peces" en los milagros de la Virgen del Carmen, que se propone representar con su compañía teatral La Barraca.

Y para quien sabe oir:

"Un golpe de mar violentísimo barrió los muelles y cubiertas de los barcos. Solo se sentía una voz sorda entre los peces que clamaba"

\section{Suicidio en Alejandria}

Todavía no cantan los peces. Vamos ahora a oirlos cantar cuando quieren cantar.

\section{LA CANCION DE LOS DELFINES}

Los únicos peces que hablan, los delfines, no son peces. Mamíferos que retornaron al mar, se piscificaron de aspecto y movimientos, pero conservaron la vocación por el sol y el aire: son heliolátricos. Como lo vieron los griegos, aman la música y el diálogo. Por ello, decidieron no pescarlos.

F.G.L. poetiza la sociabilidad de los delfines:

Delfines en hilera juegan a puentes rotos.

\section{La sirena y el carabinero.}

Alguna visión marina quedó pregnando sus ojos, o afloró en él desde los ojos de la estirpe. Y así se reitera:

Llega bárbaro puente de delfines donde el agua se vuelve mariposas, collar de llanto en las arenas finas, volante a la sin brazos cordillera.

Soledad insegura
Pero la canción del delfín, por no ser pez, se da encarnada en el hombre, del que está tan cerca como para que sea el hombre quien la cante.

En la lucha daba saltos jabonados de delfín.

\section{Muerte de Antoñito el Camborio}

$\mathrm{Y}$ no se puede describir mejor la agilidad lustrosa del gitano en pelea que llamar a sus saltos... de delfín. Pero esto hubiera sido comparación al alcance de cualquiera, sacrificando al Camborio de Antoñito. No. Antoñito es Camborio y no delfín; eso sí, sus saltos están jabonados de delfín, muestran la gracia, el duende, del salto del delfín. Por ello, Antoñito, al saltar baila la canción del delfín con el que se ha jabonado.

\section{LA CANCION DE LOS PECES SORPRENDIDOS O LA LUJURIA}

Pasadas las crisis religiosas de la adolescencia, F.G.L. buscó la construcción pagana del mundo. Acaso afloró en él, desde ese inconsciente colectivo, la raíz del dinamismo bi-sexual de la especie en forma de canción. La famosa canción del coito:

Sus muslos se me escapaban
como peces sorprendidos,
la mitad llenos de lumbre,
la mitad llenos de frío.

La casada infiel

En un sentido formal, el coito puede definirse como contacto reiterado de dos pieles. Para que sea "consumado", eyaculación masculina (no tiene la misma condicción culminativa el orgasmo femenino). Pero estos términos no recogen aspectos fundamentales de la interacción en el coito, los cuales pueden faltar ciertamente según la disposición recíproca de los cuerpos, como es por lo demás lo habitual en la ubicación de los cuadrúpedos y cuadrumanos. Ha sido la traslación del macho (consecuencia de adoptar la posición erecta del hombre) a la parte frontal de la mujer, lo que ha elevado a categoría sexual fundamental la participación coital de los muslos femeninos. En la posición cuadrúpeda o cuadrumana, la región 
genital de la hembra queda expuesta. En la posición erecta, la región genital queda en la ubicación del entre los muslos, adquiriendo hacia el frente la curvatura del cunneus o concha (de alli, la concha tridimensional de la Afrodita clásica).

La disposición coital en la especie ya humana, ha ofrecido, por culturas, variantes dominantes. En Occidente, desde el medievo, e impuesta por la estructura clerical eclesiástica como la "natural", hasta la crisis de apertura a fines del XIX, fue la de superposición frontal del macho sobre la hembra, intercalando el macho sus muslos entre los de la hembra, con lo cual ambos genitales quedan enfrentados. De ahí la utilización tan frecuente desde el Siglo de Oro español de la palabra muslos como supletoria de la palabra sexo, y la expresión "abrir los muslos" como cuasi-puritano eufemismo por la penetración vaginal. Este proceso evolutivo fue unido a dos "censuras" puestas de manifiesto por la historia del traje. La primera, la importancia dada a las "enaguas" o "faldas" como cobertura protectora del sexo de la mujer:

Sueño flor adormecida en el valle de la enagua.

\section{Canción con movimiento}

Es de tener en cuenta que tal cobertura, en un principio, constituyó una masculinización del aspecto femenino, ya que la falda o túnica siempre había sido atuendo masculino. Pero, al trastocarse los atuendos en el siglo XIX (abandono del faldellín por el varón y su adopción por la mujer), pasó a ser símbolo de lo que recataba:

Bajo las estremecidas estrellas de los velones, su falda de moaré tiembla entre sus muslos de cobre.

\section{Muerte de la petenera}

Con arreglo a la ley que regula la apetencia sexual masculina (mayor atractividad del "fruto prohibido"), la imaginación del varón occidental desplegó un complexus muslos--sexo, diferente por ejemplo al romano (posición perpendicular: caderas--sexo) o al esquimal (lateral flancos-sexo), sin entrar en imágenes incompletas.

No entraré en el detalle histórico de los matices (tobillo, pantorrilla, rodilla, parte media del muslo) en el proceso en sociedad industrial de acortamiento de la enagua o falda; o del retorno por la mujer al uso del pantalón precisamente como mayor defensa que la falda frente a las manos masculinas.

Los muslos se le escapaban como peces sorprendidos, en los versos de F.G.L., denotan ya la estancia en la culminación del proceso de penetración vaginal, pero con la pretensión de mantener el contacto a lo largo de muslos con muslos. Es decir, no simplemente la intercalación de los muslos masculinos en el entre los femeninos, sino la elevación del contacto longitudinal de muslos a condición de orgasmo.

La segunda censura establecida fue precisamente la de la prohibición eclesiástica de ese placer, impuesta mediante el conocido como "camisón católico" (usado por la mujer, con una abertura que permitía el coito, sin contacto de muslos).

De una soltera--virgen, canta F.G.L.:

Nadie besará tus muslos de brasa

Elegia

Sobreentendiendo la ausencia de esta segunda censura señalada. En ese verso, besar designa la introducción vaginal, como galicismo.

La canción de los peces sorprendidos eleva a ser permanente la fugitariedad del contacto logitudinal de los muslos simultaneado con los movimientos pélvicos conexos a la penetración vaginal.

No hay explicación que supla a la experien. cia personal para captar el sentido profundo de la comparación: solamente quien ha visto "peces sorprendidos" vive el valor pletórico de los versos de F.G.L.

Dos peces toman el sol en un playón poco profundo. Sus cabezas, inmóviles como los cuerpos, mantienen los ojos a ras del agua, de pronto, un leve ruido, una sombra no esperada... y un coletazo vigoroso los proyecta a la profundidad.

El pez-sorprendido se abisma.

Tus muslos como la tarde 
van de la luz a la sombra.

\section{Lucia Martinez}

En el caso del abismarse del pez-sorprendido, el pescador pierde la presa. En el caso de la casada infiel, es precisamente el triunfo la que provoca el abismarse de los muslos femeninos. Según Hipócrates, el coito es un leve ataque de epilepsia. La culminación de la crisis obnubila o hace perder el contacto longitudinal de los muslos.

Claro es que en la disposición masculina de la obsesión por el coito, no hay peces-sorprendidos. Se da la directa búsqueda del sexo femenino:

Niña, deja que levante

Tu vestido para verte.

Abre en mis dedos antiguos

la rosa azul de tu vientre.

Preciosa tira el pandero

y corre sin detenerse.

El viento-hombrón la persigue

con una espada caliente.

Preciosa y el aire

Las imágenes sexuales ("rosa azul de tu vientre" y "espada caliente") son sobrado explícitas para necesitar denotación. Sin embargo, el poeta vive presente los peces--sorprendidos. Es más, se da realmente su condición radical de sorprendidos, pues se abisman: Preciosa... corre...

Si el abismarse o huir radical de... Preciosa fracasa, y fuere alcanzada por la "espada caliente", el macho obseso, el macho que es "dedos antiguos" (impulso de la especie y no individual), se apodere del sexo femenino:

Los azabaches recónditos

oscurecen tus magnolias

\section{Lucia Martinez}

El color rojo oscuro casi azabache de los labios mayores del sexo de la mujer, oscurecen o dejan en la oscuridad, los muslos, blancos como magnolias: el pez-sorprendido, es atrapado en su abismarse por quien lo asustó.

F.G.L., para definir la miel (la miel de las abejas), cantó:
Dulcísima. Dulce. Este es tu adjetivo.

Dulce como los vientres de las hembras.

\section{El canto de la miel}

En otra ocasión, es una traslación de la actitud en que escultores y pintores muestran a la mujer, perfilada como Afrodita-Venus, con mano que a la vez oculta y señala el sexo:
Aunque estás muy lejana
yo te veo
llevar la mano de iris
a tu sexo,
y arreglar indolente
el almohadón del cielo.

Venus

Claro está que el "almohadón del cielo" es dúplice: tanto los cielos siderales como el cielo de la concha o bajo vientre poblado de vello.

Es la blasfemia del Prólogo la que nos muestra la plenitud de la penetración posesiva por el varón. Y es el lenguaje vernacular más conspicuo (desgarrar sus muslos limpios) el que da la plenitud de la riqueza existencial de un ser sexuado.

En esa plenitud, los peces-sorprendidos o muslos femeninos sirven de camino al falo, visto también como pez:

Además, Satanás me quiere mucho, fue compañero mío

en su examen de

lujuria, y el pícaro

buscará a Margarita

-me lo tiene ofrecido-

Margarita morena,

sobre un fondo de viejos olivos,

con dos trenzas de noche

de estío,

para que yo desgarre

sus muslos limpios,

y entonces, joh Señor!

seré $\tan$ rico

o más que tú,

porque el vacío

no puede compararse 
Y el falo desgarra los muslos:

Amor, amor

Entre mis muslos cerrados

nada como un pez el sol.

\section{Amor de don Perlimplin}

Las metáforas lorquianas son claras. No las inventa: las recoge de la experiencia de la especie. El sol o falo fecundante, nada o se agita convulsivo, como un pez, ardiente y frío simultáneamente, en el entre posesivo de los muslos cerrados.

\section{CANCION DE LOS PECES DESLUMBRADOS}

Pero los muslos cerrados ya han dejado de ser peces-sorprendidos, para pasar a ser poseedores del instruso: el pescador pasa a ser pescado. El pez-falo es atrapado en el círculo poderoso de los muslos cerrados que al cruzar los tobillos enmarcan los muslos del varón en cárcel férrea. Ya son peces deslumbrados por el sol:

\section{Déjame pasar la puerta \\ donde Eva come hormigas \\ y Adán fecunda peces deslumbrados. \\ Déjame pasar, hombrecillo de los cuernos, \\ al bosque de los desperezos \\ y los alegísimos saltos.}

\section{Poema doble del Lago Edén.}

Se trata de una descripción, no por cantada menos literal, del coito. El varón pasa de los desperezos a los saltos, mientras Eva come hormigas por todo su cuerpo, y ello en el proceso de deslumbramiento de los peces-muslos, camino hacia el sexo de Eva. Por supuesto, el "hombrecillo de los cuernos" es Dyonisos, y l "puerta" scn las labios mayores del sexo de Eva.

Pero, ¡ es tan bello cuando F.G.L. canta! :

Y Adán fecunda peces deslumbrados.

\section{CANCION DE LOS DOS PECES QUE LLAMAN}

Es ya viejo problema sin solución en Erotología el proceso por el cual en la especie humana las mamas de la mujer-mamífera han desarrollado condiciones peculiares de zona erógena secundaria. Es la única especie de mamífero, la humana, en que las mamas de la hembra han adquirido tal atractivo. Además, no en todas las épocas y culturas, pues numerosas culturas asiáticas, africanas y oceánicas no lo alcanzaron hasta la europeización.

En forma documentada (los frescos) es en la antigua Creta donde se inició (acaso paralelamente en el Alto Egipcio) la valoración estética de la silueta femenina, contra el ideal (y la realidad) estreatopígico, general antes en el Mediterráneo. Es con el dominio de la vida urbana como se valora el perfil del cuerpo femenino: el triunfo de la cintura estrecha. Claro es que en ello hubo razones prácticas por el nuevo tipo de vida, y la exaltación de la esfericidad se conservó siempre en la vida campesina sedentaria.

Con la valoración de la cintura estrecha, la valoración del perfil de las mamas. Es de suponer, sin que ello suponga atrevimiento, un resto en el varón adulto de recuerdo no consciente del placer de la succión del pezón materno en la lactancia. Sin embargo, el varón adulto sufre de una inhibición poderosa ante la mama femenina productora-de-leche-para-el-hijo. Fue precisamente cuando la mama no segrega leche cuando adquirió los caracteres de zona erógena secundaria.

Poéticamente:

Thamar, en tus pechos altos hay dos peces que me llaman.

Thamar...

En estos dos versos, verdadera canción, F.G.L. plasma poéticamente todos los elementos importantes: los pechos son altos, es decir, no han adquirido el desarrollo de las ubres del ama de cría; por tanto, se alzan sobre una cintura estrecha (el cinturón de Venus, el aro de oro de los cretenses); cada uno de ellos encierra un pez, es decir, posee atracción magnética; y llaman: a las manos y a los labios.

La misma canción, Thamar, tras la violación canta:

Paños blancos enrojecen

en las alcobas cerradas.

Rumores de tibia aurora

pámpanos y peces cambian. 
Los dos primeros versos aluden claramente a la ruptura con sangre de la telilla del virgo, y a la importancia, en las culturas matrilineales, de dicha ruptura en forma extra-marital, o sea, perdida en adelante la seguridad de la ascendencia paterna "legítima". Los versos 3 y 4 son los que interesan. Los "rumores de tibia aurora" señalan que el coito violador ha sido fecundo en el vientre de Thamar: se inicia una aurora en la matriz. Y los "rumores" (es decir, las modificaciones hormonales) provocan cambios en los pámpanos y peces. ¿Los pámpanos en la mujer preñada? El feto mismo con su placenta. ¿Los peces cambiados? Los pechos ya mamas en actividad pre-secretoria.

Para el hijo, las mamas serán manantial.

Para el adulto, son peces. Y peces tanto por su canto como por su perfil.

Por qué me diste llenos

de amor tu sexo de azucena

y el rumor de tus senos?

Madrigal de verano

Porque de perfil son exactamente un jurel que avanza, y porque poseen el rumor de la mudez que habla.

El perfil de los dos peces-pechos de la mujer es decisivo. Y si algo de femenino tiene el torero (el único artista sin ninguna fama homosexual, el macho por excelencia), es el perfil. Y para ser plenamente elegante, lo mismo que el jurel, Antoñito el Camborio "tres golpes de sangre tuvo/ y se murió de perfil".

Por eso, en La balada del agua del mar, la "joven turbia con los senos al aire" vende "el agua de los mares".

La sabiduría popular castellana (y andaluza) sintetizó la canción en un refrán: "Más tiran tetas que carretas" (10)

\section{CANCION DEL PEZ DEL MAR DE LA CHINA}

El viejo marinero ya no es navegante. Pero no ha dejado de ser marinero. El mar lo ha marcado para el siempre del resto de su vida. En su corazón acuna la canción de un pececillo que se ha venido con él, bien metido en su sangre:
Se trajo en el corazón un pez del Mar de la China.

A veces se ve cruzar diminuto por sus ojos.

Olvida siendo marino los bares y las naranjas.

Mira al agua.

Dos marineros en la orilla.

Desde la Iliada hasta Ibsen, mucho se ha escrito, y vivido, sobre la terrible condición del mar, que consume al hombre más entero; y mucho también sobre ese complejo atávico del mar hecho sangre del hombre marinero.

F.G.L. aquel marinero de tierra adentro, cuando necesita abrir su ánimo a un amigo, vio salir de sus dedos el dibujo de un Marinero y asi se lo escribió: 1930.

Carta a José María Chacón, entre 1921 y

\section{"(Dibujo: Marinero)}

"Este triste marinero fuma su pipa y recuerda.

"Si se descuida un momento, sus ojos se irán para

siempre al fondo del agua. ¡Qué lento mar sin velas $y$

recuerdos estará a estas mismas horas moviéndose! ¡Qué

mar cubierto de obscuras rosas y peces muertos! ¡Y qué

real y verdadero!

¡A la hora del oro! ¡Vive la hora! ... todos estamos

como el marinerito. De los puertos nos llegan el rumor

de los acordeones y el turbio ruido enjabonado en

los muelles, de las montañas nos llega el plato de

silencio que comen los pastores, pero nosotros no

oímos más que nuestras lejanías. ¡Y qué lejanías 
sin fondo $y \sin$ puertas $y$ sin montañas!

"Tenia que dirigirme a tí de esta manera. Tu

marinero entenderá a mi marinero".

F.G.L. está como el marinerito: "nosotros no oímos más que nuestras lejanías". Esas lejanias son las canciones del "mar cubierto de obscuras rosas y peces muertos". Es el eco de las canciones de los marineros cuya sangre trasegada ha llegado al poeta y refluye por sus labios.

Será en Nueva York donde los "peces muertos" cobran nueva mala vida en la canción.

$Y$ cuando se encuentra ante marineros, lo que él pudo haber sido, lo que fluye desde la estirpe en él, los admira y se enjabona de marinero:

"Luna tendida, marinero en pie", dicen allá, por el Mediterráneo, las gentes de veleros y fragatas.

¡Como ellos, hay que estar siempre acechando!

\section{Mariana Pineda}

En algún momento, la tentación de Narciso llevará a F.G.L. a mirarse en el fondo del río y verse, y en los "blancos ojos" de su imagen verá cruzar los "peces dormidos", los mismos que el otro se trajo del Mar de la China.

Narciso.

Tu olor.

Y el fondo del río.

Quiero quedarme a tu vera.

Flor del amor.

Narciso.

Por tus blancos ojos cruzan

ondas y peces dormidos

Narciso

Dormidos le cantaban los peces la canción de Narciso a F.G.L.

En los poemas de F.G.L. encontramos dos peceras. Las dos son bellas. Es una, la de Mariana Pineda, "un pez de plata finge rojo sueño". En la otra, la de Salvador Dalí, es una pecera para contener un pez, tal como la pintó el pintor que no podía pintar peces sin pecera... según F.G.L.

La de Mariana Pineda es un piropo. Y como es un piropo andaluz, tiene duende. En realidad, la realidad mágica del poeta "el pez de plata", no está en la pecera; ésta vive solamente para reflejar el que había en los ojos de la mujer:

"... Dijo que en tus ojos
había...
Un temblor divino, como de agua clara,
sorprendida siempre bajo el arrayán
o un temblor de luna sobre una pecera
donde un pez de plata finge rojo sueño".

Mariana Pineda

Es pues un pez que se finge dormido en los ojos de Mariana Pineda. ¿Su tentación narcisista? Otra vez, será un mancebo mismo el que reflejará desde sí mismo el Narciso de F.G.L.: Tritón enamorado.

Tu juglar fue un mancebo con escamas de plata $y$ un eco de trompeta su acento enamorado.

Elegia a Doña Juana la loca

No hay metáfora. El mancebo lleva la cota de mallas: literalmente está cubierto "con escamas de plata". Pero será uno de aquellos peces dormidos que cruzan por los ojos de Narciso. Y a F.G.L. llega el eco de su acento: remota canción del pez del Mar de la China a una reina loca.

Pero F.G.L. era demasiado complicado para limitarse a una canción romántica. Su narcisismo fecundo culminó en inconsciente blasfemia:

...

y el toro sueña un toro de agujeros y de agua.

Nacimiento de Cristo

El macho sueña un macho, es decir, con falo, pero doblemente hembra: con vagina-agujeros y con menstruo -agua. El andrógino taurino.

Canciones niuyorquinas: los peces cristalizados, los peces de arsénico, los peces aplastados, el pez muerto, los peces voladores. 


\section{F.G.L.}

Poéticamente, Nueva York le cayó mal a

Digo que le cayo mal tanto por lo que de Nueva York escribió, como porque el conjunto de poesias Poeta en Nueva York es lo más mediocre, lo menos poético de F.G.L.

"He dicho un poeta en Nueva York y he debido decir Nueva York en un poeta. Un poeta que soy yo".

Aunque F.G.L no había sido pescador, va a ser la imagen del pescador de caña el símbolo de una población humana caótica:

"El pueblo corría por las almenas rompiendo las cañas de los pescadores": Niña ahogada en el pozo. laguna:

Nueva Kork es, por ejemplo, una pútrida

No, no son los pájaros.

No es un pájaro el que expresa la turbia fiebre de laguna,

Pero el verdadero dolor estaba en otras plazas.

donde los peces cristalizados agonizaban dentro de los troncos;

\section{Panorama cicgo de Nueva York}

Esos peces cristalizados (¿los vería desecados en algún escaparate? ) son venenosos:

peces de arsnénico como tiburones, Tiburones como gotas de llanto para cegar una multitud.

\section{Grito hacia Roma}

Los tiburones no tienen canción: sólo hora, dientes y aleta triangular.

Pero es más probable que los únicos peces que vio F.G.L. en Nueva York estuvieran congelados: esos "viejos peces aplastados" (Luz panorama de los insectos). Peces aplastados, de arsénico, cristalizados, producto industrial de cadenas en serie que ya ha dejado de ser el pez bullente y brillante. ¿Qué diferentes los peces que vio vender adolescente en su Granada! : "Pasaron los vendedores de frutas y los que venden peces del mar" (Poemas en Prosa, Santa Lucia...).
Pero va a ser el pez muerto quien sintetiza a

F.G.L. como poeta en Nueva York:

Saqué una pata de gallina por detrás de la luna y luego

comprendía que mi niña

era un pez

por donde se alejan las carretas.

Yo tenía una niña.

Yo tenía un pez muerto bajo las cenizas de los incensarios.

Yo tenía un mar. ¿De qué? ¡Dios mío! ¡Un mar!

Subí a tocar las campanas, pero las frutas tenían gusanos

Iglesia abandonada

Siguiendo la versificación, el primer escalón es: "mi niña era un pez". El segundo: "Yo tenía un pez muerto bajo las cenizas de los incesarios". El primero es una explosión homosexual...: la niña con falo. El segundo, a primera lectura, es la fe infantil muerta. A segunda lectura, es la aceptación del papel pasivo en el coito homosexual.

Será cuando F.G.L. se aleje de Nueva York, cuando los peces cristalizados resuciten. Ya en el mar, serán los peces voladores quienes cantan la Nueva York bella... a la distancia.

"Arista y ritmo, forma y angustia, se los va tragando el cielo - prosigue-. Ya no hay lucha de torre y nube, ni los enjambres de ventanas se comen más de la mitad de la noche. Peces voladores tejen húmedas guirnaldas, y el cielo, como la terrible mujerona azul de Picasso, corre con los brazos abiertos a lo largo del mar.

El cielo ha triunfado del rascacielos, pero Nueva York es ahora, a lo lejos, un espectáculo natural de montañas o desiertos".

\section{Entrevista.}

Aquella Nueva York lejana es "algo fantástico", de cerca, era "enemiga de la luna":

La mujer gorda, que vuelve del revés los pulpos agonizantes. La mujer gorda, enemiga de la luna, 
Paisaje de la multitud...

\section{CANCION DEL PEZ QUE LLAMABA A LA NIÑA O UNA LEVE NECROFILIA}

Ya he señalado que, desde Freud y sucesores, señalar símbolos sexuales en alguna poesía es tarea fácil. Frecuentemente, el pez simboliza el falo, y e': agua la vagina. Simplemente esto no tendría más importancia que hallar el hecho histórico de que el poeta sufrió una época de censuras de lenguaje.

Lo valioso está en que F.G.L. lo cantó. Al cantarlo, cambió todo por encima de análisis válidos para hombres prosaicos.

También es fácil, en el poema que sigue, apreciar una clara actitud de necrofilia: F.G.L. no lo supo. Escribió una canción ligera, dolido ante la niña muerta. Fue la estirpe entera la que afloró por sus labios: el pez-falo que cruza a la niña de la cabeza a los muslos, en los que no canta la canción de los peces sorprendidos, y las "dos pequeñas calabazas" o testículos, que ya no podrán eyacular, o tenerla a flote como hembra, en ella.

$\mathrm{Al}$ estanque se le ha muerto hoy una niña de agua. Está fuera del estanque, sobre el suelo amortajada.

De la cabeza a sus muslos un pez la cruza, llamándola. El viento le dice "niña", más no puede despertarla.

El estanque tiene suelta su cabellera de algas $\mathrm{y}$ al aire sus grises tetas estremecidas de ranas.

Dios te salve. Rezaremos a Nuestra Señora de Agua por la niña del estanque muerta bajo las manzanas.

Yo luego pondré a su lado dos pequeñas calabazas para que se tenga a flote, ¡ay! , sobre la mar salada.

Nociturnos de la Ventana
Puede compararse todo el romance:

Un solo pez en el agua que a las dos Córdobas junta.

Proyección directa del coito realizado: el falo incorporándose las dos Córdobas como testículos. Y no sobre el agua, como buen puente, sino hincado en el agua vaginal.

O la descripción vaginal que forma el piropo más poéticamente encantador:

Como los calamares ciegas desnuda en tinta de perfume. Carmen.

Interior

Freudianamente, la canción del pez que llamaba a la niña llevó a F.G.L. a la canción del pez luna.

\section{DIALOGO DEL PEZ LUNA}

Esta canción de F.G.L. no la he oído. Por ello, la señalo pero no sabría explicarla. A mí me sucedió lo mismo que al Marqués de Bradomín: que haciendo el balance de los pecados cometidos, lo encontró a faltar en la lista; entonces pensó en cometerlo, para completar el elenco; pero, tras la meditación, concluyó que no valía la pena.

F.G.L., el cantor de los peces deslumbrados, se dejó tentar por la canción del pez luna, la canción del amor homosexual. Con acritud protestó contra el mariquita y sus variantes (Canción del mariquita, Oda a Walt Whitman); supongo que son los homosexuales sin canción del pez luna.

La canción del pez luna le costó la vida a F.G.L. en 1936, en su Granda. Al inicio de la guerra civil, F.G.L. (que en política se declaraba mililista) fue víctima de la violenta reacción machista que se dio en ambos bandos de guerra. A veces se ha dicho que fue víctima de una rencilla entre homosexuales. Ello es falso. Como fue bien público en aquellos primeros tres o cuatro meses, se realizó una purga sistemática (la derecha y la izquierda) de homosexuales.

Ello fue entonces bien sabido y sistemático, aunque luego se lo haya querido camuflar.

Aparte de alusiones insignificantes y dudosas, el texto básico de la canción del pez luna es el 
drama El Público. Este drama, no representado hasta el presente año de 1978, el mismo F.G.L. lo consideró no representable, por probables reacciones del público (así lo pensó hacia 1930).

... : ¿y si yo me convirtiera en tierra?

... : Yo me convertiría en agua.

... : ¿Y si yo me convirtiera en agua?

... : Yo me convertiría en pez luna.

... : ¿Y si yo me convirtiera en pez una?

... : Yo me convertiría en cuchillo...

... : Llévamélal baño y ahógame. Será

la única manera de que puedas verme desnudo.

Este diálogo, y otros muchos, no necesitan de complicaciones interpretativas para mostrar la invitación al coito homosexual. Citaré solamente, pues F.G.L. fue explícito: "En último caso, ¿es que Romeo y Julieta tienen que ser necesariamente un hombre y una mujer para que la escena del sepulcro se produzca de manera viva y desgarradora?" "Romeo era un hombre de treinta años y Julieta un muchacho de quince".

El texto publicado en la edición de Obras Completas es un primer esbozo. En 1975, la Universidad de Oxford publicó una edición completa.

Sí debo señalar que el pez luna, en $E l$ Público, dialoga pero no canta. drama:

En una Entrevista, F.G.L. dijo de este

"... no hay compañía que se anime a llevarla a escena ni público que la tolere sin indignarse... Es el espejo del público... Como el drama de cada uno a veces es muy punzante y generalmente nada honroso, pues los espectadores en seguida se levantarían indignados e impedirían que continuara la representación. Sí, la pieza no es una obra para representarse; es, como ya lo he definido, Un poema para silbarlo".

\section{CANCION DE LAS NAVAJAS DE ALBACETE}

Albacete, en el sureste de España, entre otros muchos motivos, es una ciudad famosa por las navajas: cuchilla de hoja larga, plegable dentro del mango, y extensión por un muelle. Las largas fueron prohibidas por la ley hace años.

Una navaja albaceteña es fácil de guardar en el bolsillo, y es fácil de sacar, oprimir el botón del muelle y esgrimirla. Una pelea con navajas requiere una manta o chaqueta en el brazo izquierdo como escudo; si no, el navajazo es grave:
En la mitad del barranco
las navajas de Albecete
bellas de sangre contraria,
relucen como los peces.

Reyerta

Las navajas de Albacete relucen como los peces. Pero no es simplemente que se parecen: lo son. Cuando en Bodas de sangre los dos rivales se han acuchillado a muerte. la novia gime:
"Y esto es mi cuchillo, mi cuchillito
que apenas cabe en la mano;
pez sin escamas ni río,
para que un día señalado, entre las dos y las tres,
con este cuchillo se queden dos hombres duros con los labios amarillos".

Hay peces peces mortales. Los hay con púas y espinas envenenadas. A veces, los peces siderales bajan mortales sobre la tierra:

Ya es de noche y las estrellas clavan puñales al río verdoso y frío.

Paisaje

La sangre derramada por "el pez sin escama ni río" forma un reguero por la tierra. Se ennegrece, se retuerce y gana vida propia:

Sangre resbalada gime muda canción de serpiente.

Reyerta 
Esa serpiente que manifiesta los poderes subterráneos ha sido despertada por el regato de sangre. La pitón serpeará sibilina desde Delfos hasta Granada.

En el musgo de los troncos

la cobra tendida canta

\section{Thamar y Amnón}

\section{LA NOCHE SIN CANTO DE LOS PECES}

F.G.L. sólo dejó de cantar... la muerte, cantando que no tiene canción. Como vividor de la especie, como encarnación rediviva de prehistóricas canciones de peces, no oyó ningún eco de canciones de muerte. Así entonces cantó precisamente ese silencio radical.

\section{Que se pierda en la noche sin canto de los peces \\ y en la maleza blanca del humo congelado.}

\section{Canto por Ignacio Sánchez} Mejias, 3. Cuerpo presente

Una imagen atávica, desplazada cronológicamente, claro es, de la cremación del muerto y su conversión en "humo congelado", sirve de base a la afirmación del vacío total: "la noche sin canto de los peces".

¿Qué puede ser un "cuerpo presente" en "la noche sin canto de los peces"? Un muerto. Una no conciencia. Por tanto, solamente será vida oir el canto de los peces, ya que la muerte es dejar de oírlo. La disolución en nada.

Hay en F.G.L. otro epitafio igualmente terrible. El que escribió a José de Ciria, el Giocundo:

¡Vuelve hecho luna y corazón de nada!

¡Vuelve hecho luna! Con mi propia mano

lanzaré tu manzana sobre el río

turbio de rojos peces y verano.

En la muerte de José de Ciria...

Y claro es que José de Ciria volvió. Con su propia mano, F.G.L. lanzó su manzana sobre el río. Ahí lo tenemos el río, turbio de rojos peces y verano. Un río creado por F.G.L. en su canción para reinstaurar a José de Ciria en el ser. Ahí está José de Ciria, en un agosto granadino, rodeado de rojos peces, cantado para siempre. Es decir, para munca. Para nunca como el José de Ciria que no siempre sonreía, recluído ya para siempre en el país de Ninguna Parte, ese país del que no hay canción. El José de Ciria rodeado de rojos peces se lo deberemos siempre a F.G.L., pero no es el que escuchó en Granada las canciones de los peces. Su recuerdo cantado queda en esa bella pecera de rojos peces que es la canción, y nada más.

En el drama Asi que pasen cinco años, el diálogo entre la muchacha, Arlequín y el payaso, presenta en forma simbólica la temática de la jovencita enamorada, que alguna vez he llamado Complejo de flanco.

Mi amante me aguarda en el fondo del mar.

$$
\begin{aligned}
& \text { Perdí mi deseo, } \\
& \text { perdí mi dedal, } \\
& \text { y en los troncos grandes } \\
& \text { los volví a encontrar. }
\end{aligned}
$$
Abajo está.
Banderas de agua verde
le nombran capitán.

Pero cuando Arlequín la enfrenta con la "realidad" de verlo, la muchacha se asusta y duda. "No me lo darás. / No se llega nunca / al fondo del mar".

Para bajar, Arlequín le ofrece "una cuerda muy larga", hecha de:

\section{Tiburones y peces}

y ramos de coral.

Como una escena surrealista, todo queda como estaba; simplemente se tienta con un sueño en el que se ve "La rueda que gira / del viento y el mar". 
Ese amante en el fondo del mar lleva al suicidio, pues solo la Muerte permite alcanzarlo.

A veces se da una anticipación de la muerte. No hay canción de esta anticipación tampoco. Cuando la muerte se deja entrever, danza:

$$
\begin{aligned}
& \text { El aire de la llanura, empujado por } \\
& \text { pastores, } \\
& \text { temblaba con un miedo de molusco } \\
& \text { sin cosecha. }
\end{aligned}
$$

\section{Danza de la muerte}

Sin son los peces siderales quienes se reflejan en la luna para formar los peces de luz y los peces de sombra, que alumbran a los peces del agua, la muerte tiene que venir de la luna, exactamente igual que en los antiguos ritos a Hécate:

La luna le ha comprado

pinturas a la Muerte.

En esta noche turbia, ¡está la luna loca!

\section{La luna y la muerte}

La Muerte surge con mayúscula sobre una luna con minúscula. La luna muerta pinta pinturas de la Muerte, esa luna que acongoja a los hombres ciertas noches y despierta el alarido de los canes de Perséfone. Esas noches, "está la luna loca" y por eso enloquece, pues trastorna a los que oían las canciones de los peces. Esas noches, la luna desafina y alguien muere.

Cuando la luna desafina, el mar no canta canciones de peces. Se despiertan los pulpos.

Tus tristezas son bellas, mar de espasmos gloriosos, Mas hoy en vez de estrellas tienes pulpos verdosos.

Mar

Los pulpos, tan sabrosos fritos, no tienen la culpa de no cantar. Les pasa lo mismo que al caracol, que no canta ni siquiera desafinando como la rama (11).

Los pulpos no respiran belleza en el poeta. Como tampoco la pobre iguana de Nueva York:
Vendrán las iguanas vivas a morder a los hombres que no sueñan

Ciudad sin sueño

Las iguanas son tan sabrosas, acaso más, que los pulpos. No son peligrosas al hombre. F.G.L. sólo las conocía por fotografía. Pero le bastaba para no oírlas cantar.

Estas danzas de la Muerte F.G.L. no las quería para sí, quería morir bajo una luna loca, quería morir acompañado por Helíos y cantando:

Sea mi corazón cigarra sobre los campos divinos que muera cantando lento por el cielo azul herido.

¡Cigarra!

No lo logró. Murió de noche a tiros de manos de pulpos y moluscos sin concha. No le dieron la muerte del poeta que va "cantando lento".

La que él quería era:

Quiero morirme siendo

manantial.

Quiero morirme fuera

de la mar.

Quiero volver a la infancia, y de la infancia, a la sombra.

Suite del regreso

Esa muerte deseada es claramente nostalgia del claustro materno. El Manantial del que tiene nostalgia es el materno cordón umbilical, al cual desea volver... Esa es la sombra anterior a la infancia, a la que desea volver.

Por eso pudo cantarla. No era verdadera canción a la muerte, sino canción al regreso a la condición fetal.

Su última noche, F.G.L. no tuvo sol, no hubo peces. No disfrutó de muslos de mujer. Ni siquiera pudo ver una luna reflejadora de Piscis. No cantó. 


\section{LAS MEDITACIONES $Y$ LAS ALEGRIAS DEL AGUA}

He ido espigando a lo largo y a lo ancho de los poemas de F.G.L, las canciones de los peces que cantó aquel hijo del agua, como a sí mismo se llamó. He tenido que construir este mosaico, por no haberlas oído cantar al poeta en su orden, sino al azar.

Pero F.G.L. pretendió escribir la letra de las canciones en un conjunto armónico. Así lo entrevió y nos dejó en una carta (1923) el proyecto.

Todos los ríos nacen donde nacen "y desembocan en Federico García Lorca, modesto soñador e hijo del agua".

Todos los ríos son cordones umbilicales de la totalidad del agua, del agua del mar y de las aguas siderales, que por los ríos donde los peces cantan desemboca en Federico García Lorca:

"He visto (poéticamente) un libro admirable que está por hacer y que quisiera hacerlo yo. Son las meditaciones y alegrías del agua... El poema del agua que mi libro tiene se ha abierto dentro de mi alma... Una gran Vida del Agua, con análisis detenidísimos del círculo concéntrico del reflejo, de la música borracha y sin mezcla del silencio que producen las corrientes. El río y las acequias se me han entrado. Ahora se debe decir; el Guadalguivir 0 el Miño nacen en Fuente Miña y desembocan en Federico García Lorca, modesto soñador e hijo del agua... Yo veo hasta los capítulos y las estancias... Los telares del agua, Mapa del agua. El vado de los sonidos, Meditación del Manantial. El remanso. Y luego, cuando trate... del agua muerta,..."

Nos han quedado algunas canciones de esas meditaciones y alegrías del agua. Son tan bellas. Y ya cualquier hombre las canta, gracias a él.
(1) A Jorge Guillén, 1927.

(2) A Melchor Fernández Almagro, 1921.

(3) Al mismo, 1923.

(4) Al mismo, 1924.

(5) Al mismo, 1929.

(6) Al mismo, 1921.
O bien:

(8) Fragmento de carta, 1928.

(9) "E1 silencio sin estrellas" de Preciosa.

(10) Correas, vocabulario.

(11) Los encuentros del caracol aventurero.

Las ranas hacen del cauce una siringa encantada desafinada.

Paisaje. 